\title{
Hydrogeology of the Silurian and Devonian Carbonate-Rock Aquifer System in the Midwestern Basins and Arches Region of Indiana, Ohio, Michigan, and Illinois
}

\section{By GEORGE D. CASEY}

U.S. Geological Survey

Open-File Report 93-663

REGIONAL AQUIFER-SYSTEM ANALYSIS PROGRAM

Columbus, Ohio 


\section{U.S. DEPARTMENT OF THE INTERIOR BRUCE BABBITT, Secretary}

\section{U.S. GEOLOGICAL SURVEY GORDON P. EATON, Director}

For additional information write to:

District Chief

U.S. Geological Survey

Water Resources Division

975 West Third Avenue

Columbus, Ohio 93212
Copies of this report can be purchased from:

U.S. Geological Survey

Earth Science Information Center

Open-File Reports Section

Box 25286, MS 517

Denver Federal Center

Denver, Colorado 80225 


\section{CONTENTS}

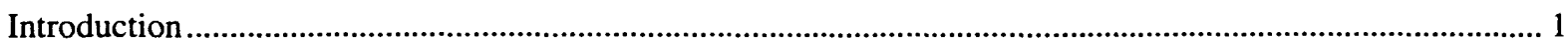

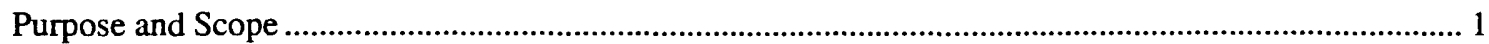

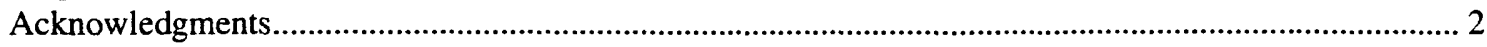

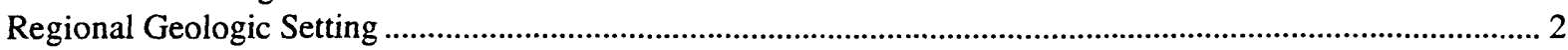

Hydrogeology of the Silurian and Devonian Carbonate-Rock Aquifer.................................................... 2

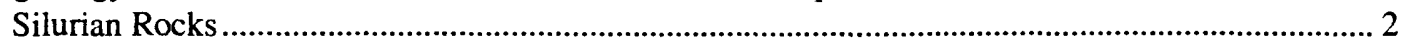

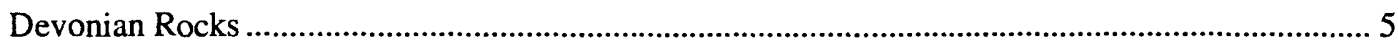

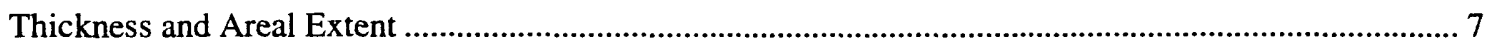

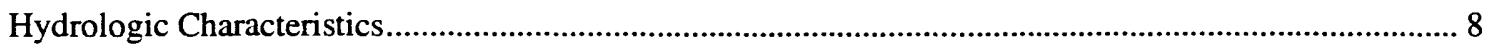

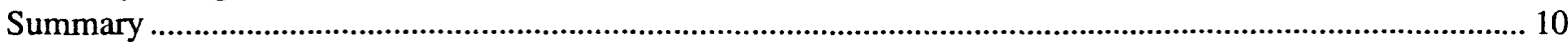

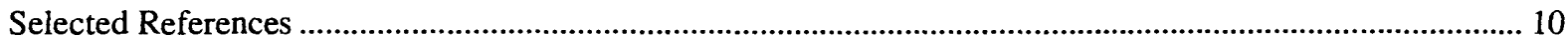

\section{PLATES}

1. Maps showing location and thickness of Carbonate-Rock aquifer system in the Midwestern Basins and Arches Region of Indiana, Ohio, Michigan, and Illinois

2. Maps showing location of oil, gas, and test holes and altitude and configuration of Carbonate-Rock aquifer system in the Midwestern Basins and Arches Region of Indiana, Ohio, Michigan, and Illinois. map envelope

\section{FIGURES}

1. Map showing location of the Midwestern Basins and Arches Regional Aquifer System Analysis area of data collection in parts of Indiana, Ohio, Michigan, Illinois, and Kentucky ............. plate 1

2. Map showing structural elements of Midwestern Basins and Arches Region of Indiana, Ohio, Michigan, and Illinois .................................................................................................................. plate 1

3. Chart showing time- and rock-stratigraphic framework and nomenclature......................................... plate 1

4-8. Map showing:

4. Location of Fort Wayne and contemporaneous bank type deposits ..plate 1

5. Thickness of the Silurian and Devonian carbonate-rock aquifer and the locations of oil, gas, and test holes used to compile thickness data for the Silurian and Devonian carbonaterock aquifer plate 1

6. Generalized location of the Teays-Mahomet River System .plate 2

7. Locations of oil, gas, and test holes used to compile the altitude data for the top of the Silurian and Devonian carbonate-rock aquifer system plate 2

8. Altitude and configuration of the top of the Silurian and Devonian carbonate-rock aquifer system 
CONVERSION FACTORS AND VERTICAL DATUM

\begin{tabular}{rrll}
\multicolumn{1}{l}{ Multiply } & By & To obtain \\
\hline foot & 0.3048 & meter \\
mile & 1.609 & kilometer \\
square mile & 2.590 & square kilometer \\
foot per day & 0.3048 & meter per day \\
foot squared per day & 0.0929 & meter squared per day \\
\hline
\end{tabular}

${ }^{1}$ This unit is used to express transmissivity, the capacity of an aquifer to transmit water. Conceptually, transmissivity is cubic feet (of water) per day per square foot (of aquifer area) per foot (of aquifer thickness). In this report, the unit is reduced to its simplest form.

Sea level: In this report, "sea level" refers to the National Geodetic Vertical Datum of 1929 (NGVD of 1929)-a geodetic datum derived from a general adjustment of the first-order level nets of both the United States and Canada, formerly called Sea Level Datum of 1929. 


\title{
Hydrogeology of the Silurian and Devonian Carbonate-Rock Aquifer System in the Midwestern Basins and Arches Region of Indiana, Ohio, Michigan, and Illinois
}

\author{
By George D. Casey
}

\section{INTRODUCTION}

This report is the second in a series that has resulted from a part of the U.S. Geological Survey's Regional Aquifer System Analysis (RASA) program, to study the Silurian and Devonian carbonate-bedrock and glacial aquifer system in the Midwestern Basins and Arches Region. The purposes of these studies are to

(1) define the hydrogeologic framework,

(2) simulate present ground-water flow, and

(3) define the present water chemistry and the geochemical basis for that chemistry in the Midwestern Basins and Arches Region (Bugliosi, 1990).

The Midwestern Basins and Arches Glacial and Carbonate RASA area of data collection covers approximately 90,000 square miles in parts of Indiana, Ohio, Michigan, and Illinois (fig. 1). This area, which is approximately 380 miles wide and 230 miles long, lies above a regional arch complex (Kankakee, Cincinnati, and Findlay Arches) and extends into three structural basins (Appalachian, Michigan, and Illinois Basins).

The regional carbonate-rock aquifer system in the Midwestern Basins and Arches Region consists of limestones and dolomites of Silurian and Devonian age. The rocks that compose the aquifer in Indiana can be grouped into four major stratigraphic units: the Brassfield/Sexton Creek Limestones or the Cataract Formation (Indiana usage), the Salamonie Dolomite (Indiana usage), the Salina Group (Indiana usage), and the Detroit River and the Traverse Formations or the Muscatatuck Group (Indiana usage). The equivalent rocks in Ohio have been categorized into distinct stratigraphic units that reflect changes in lithofacies throughout Ohio. In northwestern Ohio the rocks that compose the regional carbonate-rock aquifer are the Brassfield Limestone or the Cataract
Formation, the Dayton Limestone, the Rochester Shale equivalent, the Lockport Dolomite, the Salina Group, the Detroit River Formation, the Columbus Limestone, the Delaware Limestone or the Dundee Limestone, and the Traverse Formation. In central and western Ohio the rocks that compose the regional carbonate-rock aquifer are the Brassfield Limestone or the Cataract Formation, the Dayton Limestone, the Rochester Shale equivalent, the Lockport Dolomite, the Salina Group, the Detroit River Group, the Columbus Limestone, and the Delaware Limestone. In southwestern Ohio, the rocks that compose the regional carbonate-rock aquifer are the Brassfield Limestone, the Dayton Limestone, the Rochester Shale equivalent, the Lockport Dolomite, the Salina Group, and the Hillsboro Sandstone. Data compiled for this report were either collected during the course of this project or were derived from records available in the U.S. Geological Survey's National Water Information System data base-specifically, the Ground-Water Site Inventory (GWSI) data base from records of the Petroleum Information Corporation.

\section{Purpose and Scope}

The purposes of this report are to (1) define the regional occurrence and configuration of the hydrogeologic units that compose the carbonaterock aquifer system of the Midwestern Basins and Arches Region and (2) improve the understanding of the subsurface hydrology and geology in the Midwestern Basins and Arches Region. The hydrogeologic units of the Midwestern Basins and Arches Region are described in terms of age, stratigraphic position, depositional environment, regional stratigraphic correlations, lithology, hydrogeologic-unit surface configuration, and areal extent. 


\section{Acknowledgments}

The author gratefully acknowledges the assistance of John Rupp and Robert Shaver of the Indiana Geological Survey; John Droste of the Department of Geosciences, Indiana University; and E. Mac Swinford, Gregory Schumacher, Lawrence Wickstrom, Glenn Larsen, and Douglas Shrake of the Ohio Division of Geological Survey in collecting and analyzing much of the data presented in this report.

\section{REGIONAL GEOLOGIC SETTING}

The Midwestern Basins and Arches Region is located in the Interior Lowlands of eastern North America (King, 1977), which cover the central part of the North American craton and extend from the Appalachian Mountain System west to the Colorado Plateaus. The study area of the Midwestern Basins and Arches Glacial and Carbonate RASA encompasses northern, south-central, and southeastern Indiana; central and western Ohio; southeastern Michigan; and a small part of northeastern Illinois. This area straddles the Kankakee, the Cincinnati, and the Findlay Arches (fig. 2); the crests of these arches trend southeast-northwest with an offshoot that trends southwest to northnortheast. This structurally positive feature has been described by Shaver and others (1978) as the Wabash Platform because of the sedimentary deposition that occurred in this area. The study area is bounded on the north by the Michigan Basin, on the east by the Appalachian Basin, and on the west by the Illinois Basin (fig. 2).

The study area is underlain by Precambrian through Mississippian sedimentary rocks; however, only Late Ordovician through Mississippian rocks crop out. The sedimentary rocks of primary interest range in age from Late Ordovician through Early Mississippian. These units dip away from the crests of the arches and thicken into the adjacent structural basins. The oldest sedimentary rocks are exposed along the crest of the Cincinnati Arch in southwestern Ohio and southeastern Indiana (fig. 2) and are overlain by younger strata toward the centers of the basins. Ordovician shales also crop out along the crest of the Wisconsin Arch in northern Illinois.
The regional carbonate-rock aquifer consists of Silurian and Devonian limestones and dolomites. The rocks that compose the aquifer in Indiana and northwestern Illinois can be grouped into the following major stratigraphic units: Brassfield/ Sexton Creek Limestones or the Cataract Formation, the Salamonie Dolomite, the Salina Group, and the Detroit River and Traverse Formations or the Muscatatuck Group (fig. 3). The stratigraphic units in Ohio and southern Michigan are subdivided in greater detail than those in Indiana. In Ohio and southern Michigan, the rocks that compose the regional aquifer are the Brassfield Limestone or the Cataract Formation, the Dayton Limestone, the Rochester Shale equivalent, the Lockport Dolomite, the Salina Group, the Hillsboro Sandstone, the Detroit River Group, the Columbus Limestone, the Delaware Limestone or the Dundee Limestone, and the Traverse Formation (fig. 3).

\section{Hydrogeology of the Silurian and Devonian Carbonate-Rock Aquifer}

The physical characteristics of the stratigraphic units that compose the Silurian and Devonian carbonate-rock aquifer are largely the result of tectonic activities associated with basin subsidence and arch formation. The depositional environments that were present within the various structural basins and the different geographic locations of these equivalent units have resulted in a variety of stratigraphic nomenclature. The depositional environments within the interiors of the structural basins affected the carbonate accumulation in the distal environments that surrounded the basins.

\section{Sllurian Rocks}

During Alexandrian and early Niagaran time, tectonic events in the Great Lakes Region were continuing to be affected by the Taconic orogeny. In northwestern Ohio, northeastern Indiana, and southern Michigan, the accumulation of Alexandrian and early Niagaran carbonates was affected by depositional environments that were restricted to the Michigan Basin. This resulted in the deposition of the Cataract Formation, which is an impure and argillaceous dolomite in the upper two-thirds of the formation, and mostly a dolomite in the 
lower one-third (Shaver and others, 1986). The Cataract Formation is conformably overlain in the extreme northwestern part of Indiana by the Salamonie Dolomite, and in this area, the basal section of the Salamonie Dolomite is in a facies relation with the upper Cataract Formation (Rexroad and Droste, 1982). In most of the region, the Cataract Formation is unconformably overlain by either the Salamonie Dolomite or the Dayton Limestone.

In southeastern Indiana and southwestern Ohio, carbonate-sediment accumulation during Alexandrian and early Niagaran time was affected by the depositional environments within the Illinois and the Appalachian Basins. This resulted in the deposition of the Brassfield Limestone, which is a medium- to coarse-grained fossiliferous limestone that is locally dolomitized and contains thin noncontinuous stringers of shale (Shaver and others, 1986; Stout, 1941). The Brassfield Limestone is unconformably overlain by either the Salamonie Dolomite or the Dayton Limestone.

In the western half of Indiana, the accumulation of Alexandrian and early Niagaran carbonate sediments was affected by the depositional environments within the Illinois Basin, which resulted in the deposition of the Sexton Creek Limestone, which is a very cherty, impure limestone or dolomite. In northwestern Indiana and northeastern Illinois, the lowest section of this unit is an argillaceous dolomite or a dolomitic shale (Rexroad and Droste, 1982; Shaver and others, 1986). The Sexton Creek Limestone is unconformably overlain by the Salamonie Dolomite in the western half of Indiana with the exception of a small part of northwestern Indiana, where the Salamonie Dolomite conformably overlies the Sexton Creek Limestone (Rexroad and Droste, 1982).

The Great Lakes region underwent a period of relative tectonic quiescence during mid-Niagaran time, as compared to Alexandrian and early Niagaran time, which was accompanied by a marine transgression (Shaver and others, 1986). In western Ohio, this resulted in the deposition of the Dayton Limestone and the Rochester Shale equivalent rocks. The Dayton Limestone is a saccharoidal, coarsely crystalline, medium-bedded dolomite (Stout, 1941; Ausich, 1987). The name "Rochester Shale equivalent" refers to several members that have been described as containing soft calcareous clay-shale with thin layers of dolomite (Stout, 1941; Hull, 1990). These stratigraphic units are comparable in character to the lowest section of the Salamonie Dolomite in southeastern Indiana and the highest section of the Cataract Formation in northern and east-central Indiana (Shaver and others, 1986).

The Salamonie Dolomite comprises two distinct lithologies. The basal section of the Salamonie Dolomite generally is a fine-grained, impure, argillaceous limestone, dolomitic limestone, and shale (Shaver and others, 1986). This basal section is correlative to the Dayton Limestone and the Rochester Shale equivalent in Ohio described above. The upper section of the Salamonie Dolomite is generally a uniform, pure, white to light-gray dolomite with a coarse-grained, bioclastic, vuggy texture (Shaver and others, 1986). The correlative of the upper section of the Salamonie Dolomite in Ohio is the lower and middle section of the Lockport Dolomite.

The Lockport Dolomite conformably overlies the Rochester Shale equivalent and is conformably overlain, with minor local unconformities near reef-bank facies (Shaver, 1991), by the Salina Formation where the Salina Formation has not been eroded from above the Lockport Dolomite. In central and western Ohio, the Lockport Dolomite has been subdivided into the Gasport Dolomite, the Goat Island Dolomite, and the Guelph Dolomite (Janssens, 1977). Janssens (1977) described the Gasport Dolomite as a medium- to dark-gray, microcrystalline to coarsely crystalline dolomite. The Goat Island Dolomite is a microcrystalline to finely crystalline, light-brown to light-gray-brown dolomite (Janssens, 1977). The Guelph Dolomite is a fossiliferous, predominantly coarsely crystalline, vuggy, white to light-gray dolomite (Janssens, 1977). The term "undifferentiated Lockport Dolomite" is used in Ohio only for areas where a distinct Goat Island Dolomite lithology cannot be determined; therefore, the Lockport Dolomite includes the Gasport and the Goat Island Dolomite equivalent rocks and the Guelph Dolomite (Janssens, 1977).

Droste and Shaver (1976) described the Salamonie Dolomite as a laterally extensive, blanketlike deposit of carbonate rocks that covered the entire State of Indiana before the multiple post- 
Silurian periods of erosion. This description can be extended to the correlative Lockport Dolomite of Ohio. The pre-Devonian erosion resulted in the removal of not only the Salamonie and the Lockport Dolomites but also the Silurian strata below these units in the south-central part of the study area.

During late Niagaran time, the Great Lakes region underwent a series of marine regressions and transgressions as a result of a combination of tectonic forces exerted by (1) deposition within the structural basins, (2) emplacement of an overthrust on the eastern margin of the North American craton in the present-day Middle Atlantic States, and (3) possible eustatic sea-level changes (Shaver and Sunderman, 1983; Beaumont and others, 1988; Onasch and Kahle, 1991). The Salina Group conformably and unconformably overlies the Salamonie Dolomite and the Lockport Dolomite. The unconformities are considered to be minor local unconformities near the reef-bank facies (Shaver, 1991). The upper contact of the Salina Group is a regionally extensive unconformity. The overlying Devonian rocks range in age from Early to Middle Devonian (Droste and Shaver, 1982; Hull, 1990).

In Indiana, the Salina Group includes a diverse assemblage of dominantly carbonate rocks that range from fine-grained argillaceous rocks to a pure carbonate mud. The Salina Group also includes a coarse-grained, bioclastic, vuggy and fossiliferous facies that comprises reef-framework rocks (Shaver and others, 1986). In Indiana, south of a paleogeographic feature named the "Fort Wayne Bank" (fig. 4), the lower half of the Salina Group contains three distinct facies (Pinsak and Shaver, 1964). The lower part of the Salina Group contains a micritic to fine-grained and sucrosic dolomite; an argillaceous to shaley, fine-grained, thin-bedded dolomite; and a reef facies. The reef facies grades from a fully mature reef rock to what has been described as incipient reef rock (Shaver and others, 1986). North of the Fort Wayne Bank, the reef facies generally is absent. The dolomites that compose the remainder of the lower half of the Salina Group consist of a dark-brown micritic to fine-grained, partly laminated dolomite and a lighter colored, granular, vuggy dolomite (Shaver and others, 1986).
The upper half of the Salina Group in Indiana was deposited during latest Niagaran to earliest Cayugan time. These rocks contain several lithologies that grade into one another across the western half of the study area (Shaver and others, 1986). The lithologies of these rocks include a dense to fine-grained, calcareous, silty dolomite; a dolomitic, silty limestone; a fine-grained, lightcolored limestone; a dolomitic limestone; and a dolomite. Also included are a micritic to finegrained, thinly laminated limestone; a granular, vuggy dolomite; and carbonate mudstones that are contained within the bank, reef, reef-detrital, and biohermal deposits.

This upper section of the Salina Group has been subjected to post-Cayugan, pre-Middle Devonian subaerial exposure and erosion. This is evident, for example, where the uppermost section of the Salina Group is exposed within a quarry. At several locations in Indiana where the Cayugan carbonates have not been removed by erosion, paleokarst features are evident. The paleokarst features consist of caves, grykes, solution-widened bedding joints, and fractures derived from the settling of reef-flank deposits (Shaver, 1989). The paleokarst features are filled with a whitish quartz sand, a shaley material, breakdown that consists of the local host rock, and what appear to be pisolites. As evidence of the age of these features in relation to the overlying sediment, Shaver (1989) described a calcareous shaley material that fills a cave that contains Devonian conodonts.

In Ohio, the Salina Group includes a diverse assemblage of carbonate and evaporate deposits. These rocks range from an argillaceous, microcrystalline dolomite, which includes a stromatolitic dolomite that represents a biohermal facies, to a sucrosic, medium-grained dolomite and bedded evaporate deposits (Janssens, 1977).

In northwestern Ohio, the Salina Group is a stratigraphic unit in which lithologies vary with the location. In the western half of northwestern Ohio, the Salina Group contains the following dominant lithologies: (1) a stromatolitic brown dolomite, (2) a partly argillaceous, silty, microcrystalline dolomite that contains some shale, (3) a microcrystalline dolomite that is partly laminated, argillaceous, and pelletal, that locally incorporates secondarily deposited gypsum (Janssens, 1977), and (4) a karsted Salina facies that contains mud 
cracks and a secondary filling of caverns with what is believed to be Devonian sediments (G.E. Larsen, Ohio Geological Survey, oral commun., 1992).

A facies change has been noted within the Salina Group of northwestern Ohio east of the Bowling Green Fault Zone, where it contains dolomite, bedded anhydrite, very argillaceous dolomite, and shale. Janssens (1977, p. 23) described it as "an important updip facies of the salt-bearing Salina rocks of eastern Ohio." This facies change in northwestern Ohio could be the result of several periods of movement along the Bowling Green Fault Zone, and their effect on depositional environments, coupled with subsidence in the Michigan Basin during this depositional episode (Onasch and Kahle, 1991).

In southeastern Ohio, the Salina Group has been subjected to a greater amount of postCayugan, pre-Middle Devonian erosion than in northwestern Ohio. Ulteig (1964, p. 34) suggested that the "Upper Silurian units under cover of the Devonian carbonates are truncated in a southwesterly direction." This erosion of the upper section of the Salina Group in southwestern Ohio leaves only the basal section, which consists of a pure crystalline dolomite that exhibits medium to massive bedding and has a sucrosic texture; an argillaceous to shaley dolomite; and a dolomite with a reeflike character (Stout, 1941).

\section{Devonian Rocks}

After the post-Cayugan, pre-Middle Devonian erosional event, the Great Lakes region was again a site of carbonate and evaporite deposition. The controlling tectonic forces of this depositional event were the Acadian orogeny and a major subsidence episode in the Michigan and the Illinois Basins (Droste and Shaver, 1983; Beaumont and others, 1988). The late Niagaran and Cayugan Fort Wayne Bank (fig. 4) also is thought to have played a large role in the deposition of the middle Devonian carbonate rocks, which, as a resistant carbonate reef-bank facies, may have functioned as a barrier or a sill during the early deposition of the Detroit River Group or the Detroit River Formation of the Muscatatuck Group (Doheny and others, 1975). Some investigators (Doheny and others, 1975; Briggs and others, 1978) have proposed that the Fort Wayne Bank was a continuous feature that extended from northwestern Indiana to northwestern Ohio. The Fort Wayne Bank, in conjunction with another carbonate bank in southern Michigan (proposed by Briggs, 1959), formed a restricted evaporite basin in northern Indiana, northwestern Ohio, and southern Michigan (Mesolella and others, 1974).

In northern Indiana, northwestern Ohio, and southern Michigan, the Detroit River Formation or the Detroit River Group was deposited during late Early Devonian and Middle Devonian time. This stratigraphic unit unconformably overlies progressively younger rocks of the Salina Group or the Salina Formation from the Wabash Platform into the Michigan Basin. In northern Indiana, the Detroit River Formation is unconformably overlain by the Traverse Formation. In northwestern Ohio, the Detroit River Formation is conformably overlain by a thin section of the Columbus Limestone. The Detroit River Formation or the Detroit River Group is described by Janssens (1970) and Shaver and others (1986) as having several distinct facies. The basal section consists of a sandy dolomicrite that grades to a fine to medium sandstone cemented with dolomite and contains thin lenses of dolomicrite; this basal unit grades upward into a finegrained laminated dolomite, dolomicrite, and dolosiltite that contains anhydrite and gypsum nodules (Janssens, 1970; Shaver and others, 1986).

In central and western Ohio, southeast of the eastern extension of the Fort Wayne Bank, the Detroit River Group, is described by Stout (1941) as a true dolomite that grades into a calcareous dolomite. This limy dolomite is finely crystalline, light to brownish gray, and finely banded and contains no evaporites. The absence of evaporites can be explained by the presence of a more open, nonrestricted depositional environment south and east of the eastern extension of the Fort Wayne Bank in central and western Ohio.

Southwestern Ohio was subjected to a large amount of erosion after early Cayugan and during Middle Devonian time. Locally, where it has not been eroded, the Hillsboro Sandstone unconformably overlies the Salina Group and is unconformably overlain by the Olentangy Shale, which compose the lowest section of the confining unit above the Silurian and Devonian carbonate-rock aquifer system. The Hillsboro Sandstone is to be a clean, very pure, well-sorted, sharp silicious sand (Orton, 1888). 
In northwestern, east-central, and southeastern Indiana, the entire middle Devonian carbonate sequence is classified as the "Muscatatuck Group" (Shaver, 1974). The Muscatatuck Group unconformably overlies progressively younger Salina Group strata from the Kankakee Arch into the Illinois Basin. In southeastern Indiana, the Muscatatuck Group is unconformably overlain by the New Albany Shale, which is the upper confining unit of the Silurian and Devonian carbonate-rock aquifer. In northwestern and eastcentral Indiana, the New Albany or the Antrim Shale contact with the Muscatatuck Group generally is unconformable, but, in places, the contact is conformable (Shaver and others, 1986).

The rocks that form the Muscatatuck Group are the Detroit River and the Traverse Formations (Shaver and others, 1986). Several carbonate lithologies compose the Muscatatuck Group. The lowest section consists of a sandy, fine-grained, quartz-rich dolomite or a dolomitic quartz sandstone overlain by a granular, vuggy dolomite. These basal units are overlain by shaley to pure granular limestone and dense, lithographic to finegrained, commonly laminated dolomites and dolomitic limestones (Becker, 1974; Shaver and others, 1986). Certain coarsely granular and fibrous anhydrite and gypsum deposits within the Muscatatuck Group correlate to the Detroit River Formation in northwestern Indiana (Becker, 1974; Shaver and others, 1986).

The Columbus Limestone in central and western Ohio unconformably overlies the Detroit River Group (where the Detroit River Group is recognized) and is unconformably overlain by the Delaware Limestone (Hall and Alkire, 1956; Dow, 1962; Hull, 1990; Larsen, 1991). The Columbus Limestone consists of a basal brown, highly crystalline and porous dolomite or dolomitic limestone. This unit is overlain by a massive, gray, fossiliferous limestone that can contain some chert (Westgate, 1926; Stout, 1941; Hall and Alkire, 1956).

In northwestern Ohio, the Detroit River Formation is conformably overlain by a thin section of the Columbus Limestone (Shaver, 1985). The Columbus Limestone is unconformably overlain by the Dundee and the Delaware Limestones, which are in a facies relation. The Dundee Limestone is a sucrosic, sandy, fine- and medium- crystalline dolomitic limestone or dolomite that contains nodular chert (Janssens, 1970). The Delaware is a fine-grained, argillaceous, and fossiliferous limestone (Janssens, 1968). The Delaware and the Dundee Limestones are unconformably overlain by the Traverse Formation.

The Traverse Formation in northwestern Ohio contains two major lithologies. The basal section of the Traverse is an argillaceous and fossiliferous, fine- to coarse-grained limestone interbedded with calcareous shale. The upper section consists of a dense to medium-crystalline dolomite that contains lenticular and nodular chert and minor interbedded shaley dolomite and shale (Janssens, 1970). The Traverse unconformably overlies the Delaware and the Dundee Limestones and is unconformably overlain by the Antrim Shale, which is the upper confining unit of the Silurian and Devonian carbonate-rock aquifer (Janssens, 1970; Hull, 1990; Larsen, 1991).

The Traverse Formation in northern Indiana is very similar to the above described strata of the same name in Ohio. In Indiana, the Traverse Formation has been recognized as containing the following distinct lithologies: (1) a basal dense, micritic, fossiliferous limestone, (2) a highly fossiliferous, lithographic and sublithographic limestone that grades into a fossiliferous calcareous shale and an argillaceous limestone from northwestern to northeastern Indiana, and (3) a cherty, dense to medium-grained dolomite that overlies both of these units (Shaver and others, 1986). The Traverse Formation unconformably overlies the Detroit River Formation. The Traverse overlies progressively younger sections of the Detroit River Formation updip from the Michigan Basin onto the Wabash Platform (Shaver and others, 1986). The Traverse is overlain conformably and unconformably by the Antrim Shale (Shaver and others, 1986). In northern Indiana, the Antrim Shale is the confining unit above the Silurian and Devonian carbonate-rock aquifer.

In central and western Ohio, the Delaware Limestone lies unconformably above the Columbus Limestone and is overlain unconformably by the Olentangy Shale (Shaver, 1985; Hull, 1990; Larsen, 1991). The Olentangy Shale is the upper confining unit of the Silurian and Devonian carbonate-rock aquifer in central and western 
Ohio. The Delaware Limestone consists of a thinly bedded limestone that contains nodules of chert and thin layers of shale. This basal section grades into an argillaceous limestone, which contains beds of chert, and a massive limestone unit (Hall and Alkire, 1956; Dow, 1962; Janssens, 1968).

\section{Thickness and Areal Extent}

In southeastern Indiana and southwestern Ohio, the thickness of the Silurian and Devonian carbonate-rock aquifer increases from the contact with the underlying Ordovician shales (the updip edge of the carbonate-rock aquifer) downdip into the various structural basins (fig. 5). The thickness of the Silurian and Devonian carbonate-rock aquifer ranges from zero at the contact with the Ordovician shales to a maximum of nearly 2,500 feet in southeastern Michigan. In a structurally high position along the crests of the arches, the aquifer units crop out and have been subjected to several extensive periods of erosion, which has resulted in the loss of entire sections of the carbonate-rock aquifer in the central part of the study area.

In Ohio, near the edge of the Appalachian Basin (along the eastern boundary of the study area), the Silurian and Devonian carbonate-rock aquifer ranges in thickness from 500 feet in the south to nearly 1,300 feet in the north. In northern Indiana and northwestern Ohio, where the study area borders the southern edge of the Michigan Basin, the thickness of the Silurian and Devonian carbonate-rock aquifer ranges from 600 feet in northwestern Indiana to 1,100 feet in northwestern Ohio near the Michigan-Ohio State line. The thickness of the Silurian and Devonian carbonaterock aquifer along the western boundary of the study area, near the northeastern edge of the Illinois Basin, ranges from 100 feet in southeastern Indiana to 600 feet in northwestern Indiana.

A major feature that affects the thickness of the carbonate-rock aquifer is the ancient TeaysMahomet River System (fig. 6). The TeaysMahomet River System flowed into the Midwestern Basins and Arches RASA study area from near the confluence of the Scioto and the Ohio Rivers. The remnant Teays-Mahomet course trends northward from the Ohio River, cuts northwest- ward just south of Columbus toward Indiana, and crosses the Ohio-Indiana State line in an east-towest orientation (Goldthwait, 1991). The TeaysMahomet River System flowed westward across Indiana in a sinuous channel and out of the study area from the west-central part of Indiana toward Illinois (Burns and others, 1985a-c; Bleuer, 1991; Gray, 1991).

The effects of this ancient drainage system on the thickness of the carbonate-rock aquifer are evident in figure 5. The hachured areas depict the subcrop of the Ordovician shales, which is the basal confining unit of the Silurian and Devonian carbonate-rock aquifer system. The basal confining unit crops out beneath the unconsolidated sediments within the buried valley in areas where glaciofluvial erosion has downcut through the carbonate-rock aquifer.

In Indiana, the Silurian and Devonian carbonate-rock aquifer is cut by the following major faults: the Royal Center, the Fortville, and the Mount Carmel (fig. 5). These faults, which are located along the northeastern and eastern edges of the Illinois Basin (fig. 2), are thought to represent movement during Mississippian and Pennsylvanian time (Melhorn and Smith,1959; Shaver and Austin, 1972). Vertical displacement along these faults generally is thought to be less than 200 feet. The altitudes of the Silurian and Devonian carbonate-rock aquifer near the Mount Carmel and the Royal Center Faults were determined by Bassett and Hasenmueller (1979).

In Ohio, the Silurian and Devonian carbonaterock aquifer is displaced by faults within the Bowling Green Fault Zone (fig. 5). A large number of multiple faults have been mapped within this fault zone (VanWagner, 1988), which extends from northwestern Ohio into southeastern Michigan along the western edge of the Appalachian Basin. Movement along this feature may have taken place during early Paleozoic time but could have occurred as recently as Mesozoic or even Cenozoic time (Onasch and Kahle, 1991). Vertical displacement along the Bowling Green Fault Zone ranges from 90 to 300 feet (VanWagner, 1988).

Data used to compute the altitude of the top of the Silurian and Devonian carbonate-rock aquifer beneath the Pleistocene unconsolidated deposits were obtained primarily from the Indiana and the Ohio Geological Surveys; supplemental informa- 
tion was obtained from the Petroleum Information Corporation's data base and from deep-test-well data from GWSI. The locations of the data points are shown in figure 7 . The structure contours within the subcrop limit of the Silurian and Devonian carbonate-rock aquifer are based on published information from Gray (1982) and Bunner (1993).

The altitude and configuration of the top of the Silurian and Devonian carbonate-rock aquifer are shown in figure 8. Within the subcrop area of the Silurian and Devonian carbonate rocks, the top of the aquifer is the bedrock surface. A broad area of low relief on the top of the Silurian and Devonian carbonate-rock aquifer is depicted along the southern edge of the Michigan Basin. Where the aquifer units dip beneath overlying strata into the Michigan Basin, the slope (the change in altitude over distance) of this surface is noticeably less steep than that depicted where the aquifer units dip into the Illinois and the Appalachian Basins.

\section{Hydrologic Characteristics}

The permeability of a carbonate rock is the result of primary openings that form when the carbonate sediment is deposited or precipitated and secondary openings that have formed after the sediment has been lithified. The carbonate rocks that form the Silurian and Devonian carbonaterock aquifer have been affected by many processes that control the ability of the various geologic units to transmit water. These processes include cementation, recrystallization, micritization, solution, dolomitization, uplifting, faulting, unloading, and weathering (Brahana and others, 1988). Many of these processes can either increase or decrease the ability of carbonate rocks to transmit water.

In the Silurian and Devonian carbonate-rock aquifer, certain facies have a porous and vuggy texture, noted in the section "Geologic Characteristics." This texture can be the result of various diagenetic processes that can increase the porosity and permeability of the carbonate-rock aquifer in the facies that have been subjected to these diagenetic processes. Throughout the Silurian and Devonian carbonate-rock aquifer, rocks that have this porous and vuggy texture can be laterally equivalent to dense rocks that do not have this texture. These relations are present throughout the Silurian and Devonian carbonate-rock aquifer. At a regional scale, the areas of diagenetically controlled increase or decrease in permeability are not mappable.

The source of ground water derived from the Silurian and Devonian carbonate-rock aquifer is primarily those zones of rock that contain openings along joints, fractures, and bedding planes (secondary permeability). Some of these openings have been enlarged by dissolution as ground water flowed through the joints, fractures, and bedding planes. The magnitude and degree of interconnection between these openings determine the ability of the rock to transmit and yield water. The matrix of the carbonates also contains water that contributes to the ground-water flow system (primary and secondary permeability), but this water is assumed to be insignificant when compared to the quantities of water that move through the joints, fractures, and bedding planes (L.D. Arihood, U.S.Geological Survey, written commun., 1992). Results of a series of aquifer tests in northwestern Indiana showed that "almost all of the transmiss-ivity is derived from horizontal fracturing; how-ever, only a few fractures present in the carbonate are transmissive" (L.D. Arihood, written commun.,1992). Transmissivities determined from the aquifer tests in northwestern Indiana ranged from 300 to 27,000 feet squared per day.

The upper zone is the most highly fractured zone of the Silurian and Devonian carbonate-rock aquifer (the strata at or near the bedrock surface regardless of the lithologic unit) as compared to more deeply buried zones and generally contains the greatest number of enlarged openings. This prevalence of fractures and enlarged openings is a result of weathering of the bedrock and unloading, which causes horizontal joints along bedding plains to open. At depths greater than 250 to 300 feet below land surface, however, these fractures generally are not thought to be capable of transmitting water because the weight of the overlying strata limits the unloading-related fracturing and because secondary mineralization of the fractures limits the size of the openings between the fracture walls. The Great Lakes region has been subjected to several glaciations, and some investigators (Beaumont and others, 1988) have postu- 
lated that a thick sequence of sedimentary rock was deposited on top of the carbonate-rock aquifer and has since been removed from the study area. The removal of the overlying strata, coupled with the multiple glacial advances and retreats, allowed the unloading-related joints to form preferentially at preexisting points of weakness in the Silurian and Devonian carbonates (Kappel and Tepper, in press).

Some intervals within the Silurian and Devonian carbonate-rock aquifer below the upper fractured zone have an increased transmissive capability compared to the rest of the carbonaterock aquifer. The "Newburg zone," which is a term used by the oil and gas industry in eastern Ohio for one of these zones, was documented by Norris and Fidler (1971). This zone is in the carbonate strata overlying the Lockport Dolomite, which is principally the lower section of the Salina Group (Norris and Fidler, 1971). The Newburg zone is not contiguous within the study area, and other permeable zones have been noted in a broader stratigraphic section than that described by Norris and Fidler (1971). Strobel and Bugliosi (1991, p. 214) proposed that the Newburg zone could be the result of multiple diachronous processes. Because of the lack of evidence that this zone is laterally extensive, it is probably not regionally important as a water-bearing zone but could be significant locally.

The carbonate rocks at and above a regionally extensive erosional surface (the Silurian-Devonian unconformity) have been observed to yield continuously large quantities of water from seeps within quarries and outcrops (Shaver, 1989). This feature has been eroded in the central part of the study area where older rocks crop out; however, the unconformity and a zone above the unconformity appear to be a less-resistant path for ground-water flow than zones either above or below it. A clastic-rich zone of Devonian age, which is contained within the lower section of the Detroit River Formation directly above the unconformity (described in the section "Geologic Characteristics"), seems to transmit ground water effectively. The underlying Silurian rock is a massive carbonate, whereas the rock from within the zone is a fine sandstone and sandy dolomite that is overlain by alternating units of argillaceous to pure bioclastic, vuggy, nonfossiliferous dolomite (Shaver, 1989). Surficial iron staining of carbonates below this zone is additional evidence that water moves preferentially within this zone as a result of the change in hydrologic character from the overlying Devonian carbonate rock to the underlying Silurian carbonate rock. This staining results from the flow of ground water out of the more transmissive zone and down the quarry face below.

Faulting of carbonate rocks can affect groundwater flow in various ways. It can increase an aquifer's ability to transmit water by fracturing the rock, thereby increasing the ground-water flow and the dissolution of the carbonate rock, consequently enlarging the original fractures. Faulting also can restrict the ground-water flow where a relatively impermeable unit is displaced along the fault so it is in contact with a more permeable unit.

Of the four major faults that affect the Silurian and Devonian carbonate-rock aquifer, only the Bowling Green Fault Zone has been studied with respect to its hydrologic effects. VanWagner (1988) described the variation of specific capacity (which he termed "transmissivity factor") across sections of the fault zone. He noted that the highest specific capacities were found along fracture trends, but that a number of unproductive wells were located within several hundred feet of wells with high specific capacities. This example demonstrates that hydrologic characteristics can vary widely over short distances within a feature like the Bowling Green Fault Zone.

Hydrologic data for the Silurian and Devonian carbonate-rock aquifer in the Midwestern Basins and Arches Region have been compiled and indicate that transmissivities for the Silurian and Devonian carbonate-rock aquifer determined from aquifer tests range from 70 to 28,000 feet squared per day and storage coefficients range from 0.00001 to 0.01 (Joseph and Eberts, 1994). These transmissivities are three to five orders of magnitude greater than those cited for the Ordovician shales of the basal confining unit (Casey, 1992). Similar differences in transmissivities between the Silurian and Devonian carbonate-rock aquifer and the Upper Devonian and Lower Mississippian shales and siltstones that comprise the upper confining unit of the aquifer system have been reported (Droste and Vitaliano, 1976). Where the upper confining unit of the aquifer has been eroded the overlying glacial sediments semiconfine the carbonate-rock aquifer (S.M. Eberts, U.S. Geological Survey, written commun., 1992). 


\section{SUMMARY}

The Silurian and Devonian carbonate-rock aquifer in the Midwestern Basins and Arches Region of Indiana, Ohio, Michigan, and Illinois consists primarily of dolomite and limestone with variable amounts of terrigenous clastics and evaporites. The aquifer is underlain by a basal confining unit that is composed of a relatively impermeable and regionally extensive Ordovician shale. These units collectively form a barrier to ground-water flow across the Silurian-Ordovician boundary that effectively limits the transfer of significant quantities of water through the base of the Silurian and Devonian carbonate-rock aquifer, which is semiconfined compared with the overlying glacial sediments.

Locations of primary water-bearing zones in the Silurian and Devonian carbonate-rock aquifer are related to the degree of fracturing, depth below land surface, and lithologic variation within the aquifer. At shallow depths (less than 300 feet below land surface), the upper part of the aquifer contains the most fractured rocks and generally has the greatest number of enlarged openings. Clasticrich dolomite at and directly above the unconformity between the Silurian and Devonian carbonates forms a regional water-bearing zone. Other locally significant water-bearing zones are found in the Silurian and Devonian carbonate-rock aquifer. These water-bearing zones have been associated with local unconformities that have been described as being near-reef- and bank-type deposits.

The thickness of the Silurian and Devonian carbonate-rock aquifer ranges from zero at the contact with the Ordovician shales (the updip edge of the aquifer) to a maximum of nearly 2,500 feet in southeastern Michigan. In a structurally high position, along the crests of the arches, the aquifer units crop out and have been subjected to several extensive periods of erosion, which has resulted in the loss of entire sections of the carbonate-rock aquifer in the central part of the study area.

The Silurian and Devonian carbonate-rock aquifer has been completely eroded in places by the ancient Teays-Mahomet River System. The downcutting of the river system has caused the basal confining unit to crop out beneath the unconsolidated sediments that today fill the buried valley. The downcutting also has thinned the aquifer along the course of the ancient TeaysMahomet River System.

The Silurian and Devonian carbonate-rock aquifer is overlain and confined by Upper Devonian and Lower Mississippian shales and siltstones where the aquifer units dip into the various basins surround the study area. Elsewhere, the aquifer is overlain and semiconfined by unconsolidated Pleistocene glacial deposits.

\section{SELECTED REFERENCES}

Ault, C.H., Becker, L.E., Droste, J.B., Keller, S.J., and Shaver, R.H., 1992, Map of Indiana showing thickness of Silurian rocks and location of reefs: Indiana Department of Natural Resources, Geological Survey Miscellaneous Map 54, scale 1:500,000.

Ausich, W.I., 1987, John Bryan State Park, OhioSilurian stratigraphy, in Biggs, D.L., ed., North Central Section of the Geological Society of America; v. 3 of the Geological Society of America Centennial Field Guide: Geological Society of America, p. 419-422.

Bassett, J.L., and Hasenmueller, N.R., 1979, Map showing structure on base of New Albany shale (Devonian and Mississippian) and equivalent strata in Indiana: Indiana Department of Natural Resources, Geological Survey METC/EGSP Series 812, scale 1:500,000.

Beaumont, Christopher, Quinlan, G.M., and Hamilton, Juliet, 1988, Orogeny and stratigraphy-Numerical models of the Paleozoic in the eastern interior of North America: Tectonics, v. 7, no. 3, p. 389-416.

Becker, L.E., 1974, Silurian and Devonian rocks in Indiana southwest of the Cincinnati Arch: Indiana Department of Natural Resources, Geological Survey Bulletin 50,83 p.

Becker, L.E., and Droste, J.B., 1978, Late Silurian and Early Devonian sedimentologic history of southwestern Indiana: Indiana Department of Natural Resources, Geological Survey Occasional Paper 24, $14 \mathrm{p}$.

Bleuer, N.K., 1991, The Lafayette Bedrock Valley System of Indiana - Concept, form, and fill stratigraphy, in Melhorn, W.N., and Kempton, J.P., eds., Geology and hydrology of the Teays-Mahomet Bedrock Valley System: Geological Society of America Special Paper 258, p. 51-77.

Bownocker, J.A., comp., 1920 [1981], Geologic map of Ohio: Ohio Geological Survey, scale 1:500,000. 
Briggs, L.I., 1959, Physical stratigraphy of lower Middle Devonian rocks in the Michigan Basin, in Geology of Mackinac Island and Lower and Middle Devonian south of the straits of Mackinac: Michigan Basin Geological Society Guidebook, p. 39-56.

Briggs, L.I., Briggs, D.Z., Elmore, R.D.,and Gill, Daniel, 1978, Stratigraphic facies of carbonate platform and basinal deposits, late Middle Silurian, Michigan Basin, in Kesling, R.V., ed., The northcentral section of the Geological Society of America, Field excursions from the University of Michigan: Geological Society of America, p. 117-131.

Brahana, J.V., Thrailkill, John, Freeman, Tom, and Ward, W.C., 1988, Carbonate rocks, in Back, William, Rosenshein, J.S., and Seaber, P.R., eds., Hydrogeology, v. 0-2 of Geology of North America: Geological Society of America, p. 333-352.

Bugliosi, E.F., 1990, Plan of study for the Ohio-Indiana carbonate-bedrock and glacial-aquifer system: U.S. Geological Survey Open-File Report 90-151, 26 p.

Bunner, D.W., 1993, Bedrock-surface altitude in the Midwestern Basins and Arches region of Indiana, Ohio, Michigan, and Illinois: U.S. Geological Survey Water-Resources Investigations Report 93-4050, scale 1:750,000.

Burger, A.M., Forsyth, J.L., Nicoll, R.S., and Wayne, W.J., 1971, Geologic map of the $1^{\circ} \times 2^{\circ}$ Muncie quadrangle, Indiana, and Ohio, showing bedrock and unconsolidated deposits: Indiana Department of Natural Resources, Geological Survey Regional Geologic Map 5, scale 1:250,000.

1985a, Map showing bedrock topography of the Teays Valley, western part, north-central Indiana: Indiana Department of Natural Resources, Geological Survey Miscellaneous Map 42, scale 1:100,000.

$1985 \mathrm{~b}$, Map showing bedrock topography of the Teays Valley, central part, north-central Indiana: Indiana Department of Natural Resources, Geological Survey Miscellaneous Map 43, scale $1: 100,000$.

Burns, T.M., Logan, S.M., and Steen, W.J.,1985c, Map showing bedrock topography of the Teays Valley, eastern part, north-central Indiana: Indiana Department of Natural Resources, Geological Survey Miscellaneous Map 44, scale 1:100,000.

Casey, G.D., 1992, Hydrogeology of the basal confining unit of the carbonate aquifer system in the Midwestern Basins and Arches Region of Indiana, Ohio, Michigan, and Illinois: U.S. Geological
Survey Open-File Report 92-489, 2 sheets, scale $1: 1,000,000$.

Doheny, E.J., Droste, J.B., and Shaver, R.H., 1975, Stratigraphy of the Detroit River Formation (Middle Devonian) of northern Indiana: Indiana Department of Natural Resources, Geological Survey Bulletin 53, $86 \mathrm{p}$.

Dow, J.W., 1962, Lower and Middle Devonian limestones in northeastern Ohio and adjacent areas: Ohio Department of Natural Resources, Geological Survey Report of Investigations 42, $67 \mathrm{p}$.

Droste, J.B., 1976, Paleozoic stratigraphy of two areas in southwestern Indiana: U.S. Energy Research and Development Administration Report, 28 p.

Droste, J.B., and Shaver, R.H., 1976, The Limberlost Dolomite of Indiana-A key to the great Silurian facies in the southern Great Lakes area: Indiana Department of Natural Resources, Geological Survey Occasional Paper 15, 21 p.

1980, Recognition of buried Silurian reefs in southwestern Indiana-Application to the Terre Haute bank: Journal of Geology, v. 88, p. 567-587. 1982, The Salina Group (Middle and Upper Silurian) of Indiana: Indiana Department of Natural Resources, Geological Survey Special Report 24, 41 p.

1983, Atlas of Early and Middle Paleozoic paleogeography of the southern Great Lakes area: Indiana Department of Natural Resources, Geological Survey Special Report 32, 31 p.

1985, Comparative stratigraphic framework for Silurian reefs-Michigan Basin to surrounding platforms: Michigan Basin Geological Society Special Paper 4, p. 73-93.

1987, Upper Silurian and Devonian stratigraphy of the Central Illinois Basin: Indiana Department of Natural Resources, Geological Survey, Special Report 39, 29 p.

Droste, J.B., and Vitaliano, C.J., 1976, Geologic report of the Maquoketa Shale, New Albany Shale, and Borden Group rocks in the Illinois Basin as potential solid waste repository sites: U.S. Energy Research and Development Administration Report, $25 \mathrm{p}$.

Floto, B.A., 1955, The possible presence of buried Niagaran reefs in Ohio and their relationship to the Newburg oil and gas zone: Ohio Department of Natural Resources, Geological Survey Report of Investigations 24, p. 41-52.

Goldthwait, R.P., 1991, The Teays Valley problem-A historical perspective, in Melhorn, W.N., and Kempton, J.P., eds., Geology and hydrogeology of the Teays-Mahomet bedrock valley system: 
Geological Society of America Special Paper 258, p. 3-8.

Gray, H.H., 1972, Geologic map of the $1^{\circ} \times 2^{\circ}$ Louisville quadrangle, Indiana, showing bedrock and unconsolidated deposits: Indiana Department of Natural Resources, Geological Survey Regional Geologic Map 6, scale 1:250,000.

1982, Map of Indiana showing topography of the bedrock surface: Indiana Geological Survey Miscellaneous Map 36, map 1:500,000.

1991 , Origin and history of the Teays drainage system-The view from midstream, in Melhorn, W.N., and Kempton, J.P., eds., Geology and hydrology of the Teays-Mahomet Bedrock Valley System: Geological Society of America Special Paper 258, p. 43-50.

Gray, H.H., Ault, C.H., and Keller, S.J., 1987, Bedrock geologic map of Indiana: Indiana Department of Natural Resources, Geological Survey Miscellaneous Map 48, scale 1:500,000.

Gray, H.H., Bleuer, N.K., Hill, J.R., and Lineback, J.A., 1979 , Geologic map of the $1^{\circ} \times 2^{\circ}$ Indianapolis quadrangle, Indiana and Illinois, showing bedrock and unconsolidated deposits: Indiana Department of Natural Resources, Geological Survey Regional Geologic Map 1, scale 1:250,000.

Gray, H.H., Droste, J.B., Patton, J.B., Rexroad, C.B., and Shaver, R.H., 1985, Correlation chart showing Paleozoic stratigraphic units of Indiana: Indiana Department of Natural Resources, Geological Survey Supplement to Miscellaneous Map 48, 1 sheet.

Gray, H.H., Forsyth, J.L., Schneider, A.F., and Gooding, A.M., 1972, Geologic map of the $1^{\circ} \times 2^{\circ}$ Cincinnati quadrangle, Indiana and Ohio, showing bedrock and unconsolidated deposits: Indiana Department of Natural Resources, Geological Survey Regional Geologic Map 7, scale 1:250,000.

Hall, J.F., and Alkire, R.L., 1956, The economic geology of Crawford, Marion, Morrow, and Wyandot Counties: Ohio Department of Natural Resources, Geological Survey Report of Investigations $28,43 \mathrm{p}$.

Hasenmueller, N.R., and Bassett, J.L., 1980, Map showing structure on top of the Trenton Limestone (Ordovician): Indiana Department of Natural Resources, Geological Survey METC/EGSP Series 813, scale 1:500,000.

Hughes, G.M., Kraatz, Paul, and Landon, R.A., 1966, Bedrock aquifers of northeastern Illinois: Illinois State Geological Survey Circular 406, 15 p.

Hull, D.N., 1990, Generalized column of bedrock units in Ohio: Ohio Department of Natural Resources, Geological Survey, 1 p.
Janssens, Adriaan, 1968, Stratigraphy of Silurian and pre-Olentangy Devonian rocks of the South Birmingham pool area, Erie and Lorain Counties, Ohio: Ohio Department of Natural Resources, Geological Survey Report of Investigations 70, $20 \mathrm{p}$.

1970, Middle Devonian formations in the subsurface of northwestern Ohio: Ohio Department of Natural Resources, Geological Survey Report of Investigations $78,22 \mathrm{p}$.

1977 , Silurian rocks in the subsurface of northwestern Ohio: Ohio Department of Natural Resources, Geological Survey Report of Investigations $100,96 \mathrm{p}$.

Johnson, G.H., and Keller, S.J., 1972, Geologic map of the $1^{\circ} \times 2^{\circ}$ Fort Wayne quadrangle, Indiana, Michigan, and Ohio, showing bedrock and unconsolidated deposits: Indiana Department of Natural Resources, Geological Survey Regional Geologic Map 8, scale 1:250,000.

Joseph, R.L., and Eberts, S.M., 1994, Selected data on characteristics of glacial-deposit and carbonaterock aquifers, Midwestern Basins and Arches Region: U.S. Geological Survey Open-File Report 93-62, 43 p.

Kappel, W.M., and Tepper, D.H., in press, An overview of the recent U.S. Geological Survey study of the hydrogeology of the Niagara Falls area of New York, in Symposium of the International Association of Hydrologists, Hamilton, Ontario, May 1992: Proceedings, $14 \mathrm{p}$.

Keller, S.J., and Abdulkareem, T.F., 1980, Post-Knox unconformity-Significance at Unionport gasstorage project and relationships to petroleum exploration in Indiana: Indiana Department of Natural Resources, Geological Survey Occasional Paper 31, $19 \mathrm{p}$.

King, P.B., 1977, The evolution of North America: Princeton, N.J., Princeton University Press, 197 p.

LaFerriere, A.P., Hattin, D.E., Foell, C.J., and Abdulkareem, T.F., 1986, The Ordovician-Silurian unconformity in southeastern Indiana: Indiana Department of Natural Resources, Geological Survey Occasional Paper 53, 12 p.

Larsen, G.E., 1991, Development of Silurian and Devonian lithostratigraphic nomenclature, centralwestern and northwestern Ohio: Ohio Department of Natural Resources, Geological Survey OpenFile Report 91-1, 1 pl.

Melhorn, W.N., and Smith, N.M., 1959, The Mt. Carmel Fault and related structural features in southcentral Indiana: Indiana Geological Survey Report of Progress 16, 29 p., 1 pl. 
Mesolella, K.J., Robinson, J.D., McCormick, L.M., and, Ormiston, A.R., 1974, Cyclic deposition of Silurian carbonates and evaporites in Michigan Basin: Bulletin of the American Association of Petroleum Geologists, v. 58, no. 1, p. 34-62.

Milstein, R.L., compiler, 1987, Bedrock geology of southern Michigan: State of Michigan Department of Natural Resources, Geological Survey, scale 1:500,000.

Norris, S.E., 1979, Hydraulic properties of a limestonedolomite aquifer near Marion, north-central Ohio: Ohio Department of Natural Resources, Geological Survey Report of Investigations 110, 23 p.

Norris, S.E., and Fidler, R.E., 1971, Availability of ground water from limestone and dolomite aquifers in northwest Ohio and its relation to geologic structure: U.S. Geological Survey Professional Paper 750-B, p. B229-B235.

1973, Availability of water from limestones and dolomite aquifers in southwestern Ohio and the relation of water quality to the regional flow system: U.S. Geological Survey Water-Resources Investigations 73-17, $42 \mathrm{p}$.

Norris, S.E., and Spieker, A.M., 1961, Geology and hydrology of the Piqua area, Ohio: U.S. Geological Survey Bulletin 1133-A, 33 p.

Onasch, C.M., and Kahle, C.F., 1991, Recurrent tectonics in a cratonic setting-An example from northwestern Ohio: Geological Society of America Bulletin, v. 103, p. 1259-1269.

Orton, Edward, 1888, Economic geology, v. 6, Report of the Geological Survey of Ohio: Ohio Geological Survey, $831 \mathrm{p}$.

Pinsak, A.P., and Shaver R.H., 1964,The Silurian formations of northern Indiana: Indiana Department of Natural Resources, Geological Survey Bulletin 32, $87 \mathrm{p}$.

Rexroad, C.B., 1980, Stratigraphy and conodont paleontology of the Cataract Formation and the Salamonie Dolomite (Silurian) in northeastern Indiana: Indiana Department of Natural Resources, Geological Survey Bulletin 58, 83 p.

Rexroad, C.B., and Droste, J.B., 1982, Stratigraphy and conodont paleontology of the Sexton Creek Limestone and the Salamonie Dolomite (Silurian) in northwestern Indiana: Indiana Department of Natural Resources, Geological Survey Special Report 25, 29 p.

Rodgers, G.D., and Luckey, R.R., 1990, Ground-water retrieval/tabling program, in Mathey, S.B., ed., National Water Information System user's manual: U.S. Geological Survey Open-File Report 89-587, v. 2 , chap. 4 , p. 8-1-8-56.
Rupp, J.A., 1991, Structure and isopach maps of the paleozoic rocks of Indiana: Indiana Geological Survey Special Report 48, 106 p.

Shaver, R.H., 1974, The Muscatatuck Group (new Middle Devonian name) in Indiana: Indiana Department of Natural Resources, Geological Survey Occasional Paper 3, 7 p.

(regional coordinator), 1985, Midwestern Basins and Arches region-Correlation of stratigraphic units of North America (COSUNA) project: American Association of Petroleum Geologists, 1 sheet.

1989 , A field trip on the great carbonate-rock facies in the Silurian system of western Ohio and northern Indiana: Bloomington, Ind., Indiana Geological Survey and Indiana University field trip guide and supplements, $35 \mathrm{p}$.

1991, A history of study of Silurian reefs in the Michigan Basin environs, in Catacosinos, P.A., and Daniels, P.A., eds., Early sedimentary evolution of the Michigan Basin: Geological Society of America Special Paper 256, p. 101-138.

Shaver, R.H., Ault, C.H., Ausich, W.I., Droste, J.B., Horowitz, A.S., James, C.W., Okla, S.M., Rexroad, C.B., Suchomel, D.M., and Welch, J.R., 1978, The search for a Silurian reef model-Great Lakes area: Indiana Department of Natural Resources, Geological Survey Special Report 15, 36 p.

Shaver, R.H., Ault, C.H., Burger, A.M., Carr, D.D., Droste, J.B., Eggert, D.L., Gary, H.H., Harper, Denver, Hassenmueller, N.R., Hassenmueller, W.A., Horowitz, A.S., Hutchison, H.C., Keith, B.D., Keller, S.J., Patton, J.B., Rexroad, C.B., and Wier, C.E., 1986, Compendium of paleozoic rockunit stratigraphy in Indiana-A revision: Indiana Department of Natural Resources, Geological Survey Bulletin 59, $203 \mathrm{p}$.

Shaver, R.H., and Austin, G.S., 1972, A field guide to the Mt. Carmel Fault of southern Indiana: Indiana Department of Natural Resources, Geological Survey Guidebook 13, 25 p.

Shaver, R.H., and Sunderman, J.A., 1983, Silurian reef and interreef strata as responses to a cyclical succession of environments, southern Great Lakes area (field trip 12), in Shaver, R.H., and Sunderman, J.A., eds., Field trips in midwestern geology: Geological Society of America Field Trip Guide, v. 1 p. 141-196.

1989, Silurian seascapes-Water depth, clinothems, reef geometry, and other motifs-A critical review of the Silurian reef model: Geological Society of American Bulletin, v. 101, p. 939-951. 
Stith, D.A., 1972, High-calcium limestone facies of the Devonian Dundee Limestone, northwestern Ohio: Ohio Geological Survey Report of Investigation $86,14 \mathrm{p}$.

Stout, Wilber, 1941, Dolomite and limestone of western Ohio: Ohio Geological Survey Bulletin 42, 468 p.

Stout, Wilber, Ver Steeg, K., and Lamb, G.F., 1943, Geology of water in Ohio (a basic report): Ohio Geological Survey Bulletin 44, 694 p.

Strobel, M.L., and Bugliosi, E.F., 1991, Areal extent, hydeogeological characteristics, and possible origins of the carbonate rock Newburg zone (Middle-Upper Silurian) in Ohio: The Ohio Journal of Science 91, v. 5, p. 209-215.

Ulteig, J.R. 1964, Upper Niagaran and Cayugan stratigraphy of northeastern Ohio and adjacent areas: Ohio Geological Survey Report of Investigation $51,48 \mathrm{p}$.

VanWagner, Elmer, III, 1988, An integrated investigation of the Bowling Green Fault using multispectral reflectance, potential field, seismic, and well log data sets: Bowling Green, Ohio, Bowling Green State University, master's thesis, 171 p.
Walker, A.C., and others, 1970, Ground water for planning in northwest Ohio-A study of the carbonate rock aquifers: Ohio Department of Natural Resources, Ohio Water Plan Inventory Report 22, 63 p.

Wahl, K.D., and Bunker, B.J., 1982, Hydrogeology of carbonate aquifers in southwestern Linn County and adjacent parts of Benton, Iowa, and Johnson Counties, Iowa: Iowa Geological Survey Water Supply Bulletin $15,58 \mathrm{p}$.

Westgate, L.G., 1926, Geology of Delaware County: Geological Survey of Ohio, Bulletin 30, ser. 4, $147 \mathrm{p}$.

Willman, H.B., 1973, Rock stratigraphy of the Silurian system in northeastern and northwestern Illinois: Illinois State Geological Survey Circular 479, 55 p.

Willman, H.B., Frye, J.C., Simon, J.A., Clegg, K.E., Swann, D.H., Atherton, Elwood, Collinson, Charles, Lineback, J.A., and Buschbach, T.C., 1967, Geologic map of Illinois: State of Illinois Department of Registration and Education, Illinois State Geological Survey, scale 1:500,000. 